\title{
National and Regional Water and Wastewater Rates For Use in Cost-Benefit Models and Evaluations of Water Efficiency Programs
}

Diane C. Fisher, Camilla Dunham Whitehead, and Moya Melody

\author{
Water and Energy Technology Team \\ Environmental Energy Technologies Division \\ Lawrence Berkeley National Laboratory \\ University of California \\ Berkeley, CA 94720
}

For the U.S. Environmental Protection Agency

WaterSense Program

September 2006 


\section{Table of Contents}

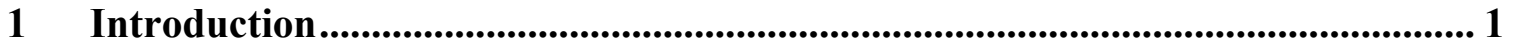

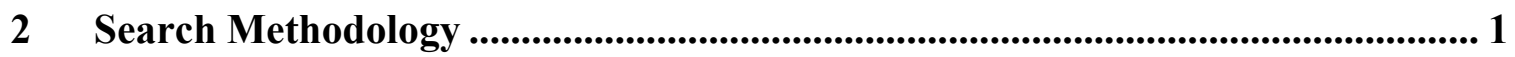

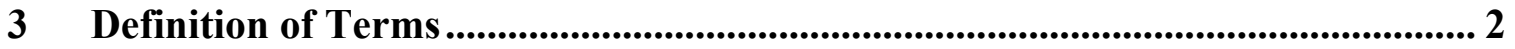

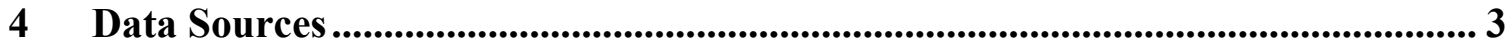

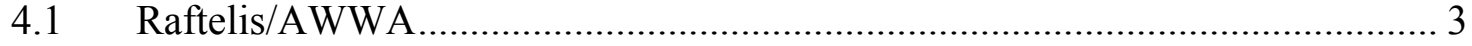

4.1.1 Calculation Methodology........................................................................... 5

4.1.2 Calculated Marginal Rates for Water ...................................................... 5

4.1.3 Calculated Marginal Rates for Wastewater ............................................ 6

4.1.4 Calculated Commercial and Industrial Marginal Rates for Water.............. 7

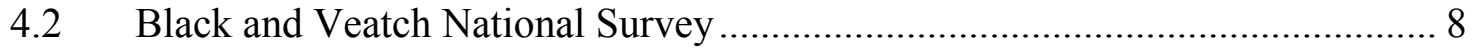

4.2.1 Calculation Methodology....................................................................... 8

4.2.2 Calculated Average Rates ................................................................ 8

4.2.3 Calculated Commercial and Industrial Rates for Water .......................... 10

4.3 American Water Works Association ............................................................ 10

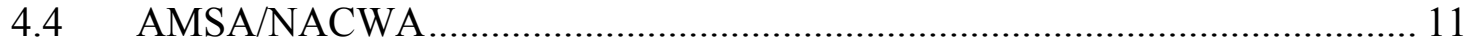

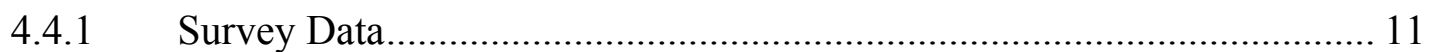

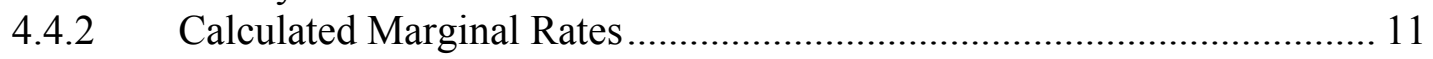

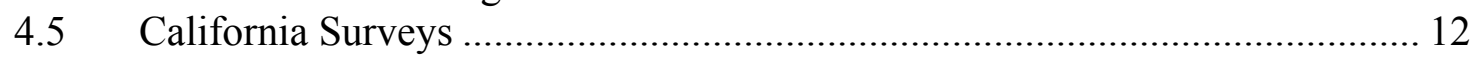

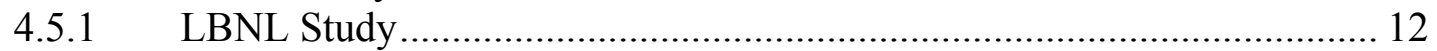

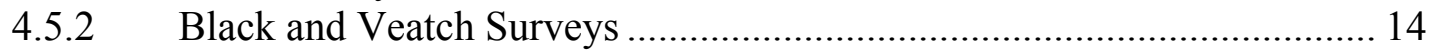

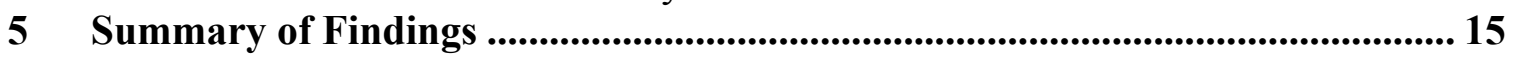

$5.1 \quad$ Average Rates for Water and Wastewater ................................................ 15

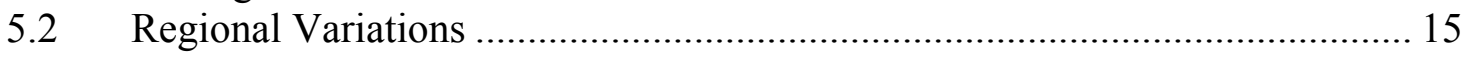

6 Past and Projected Trends in Rates ............................................................................ 16

7 Conclusions............................................................................................................ 18

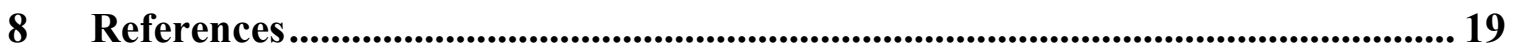




\begin{abstract}
Calculating the benefits and costs of water conservation or efficiency programs requires knowing the marginal cost of the water and wastewater saved by those programs. Developing an accurate picture of the potential cost savings from water conservation requires knowing the cost of the last few units of water consumed or wastewater released, because those are the units that would be saved by increased water efficiency. This report describes the data we obtained on water and wastewater rates and costs, data gaps we identified, and other issues related to using the data to estimate the cost savings that might accrue from water conservation programs.
\end{abstract}

We identified three water and wastewater rate sources. Of these, we recommend using Raftelis Financial Corporation (RFC) because it: a) has the most comprehensive national coverage; and b) provides greatest detail on rates to calculate marginal rates. The figure below shows the regional variation in water rates for a range of consumption blocks.

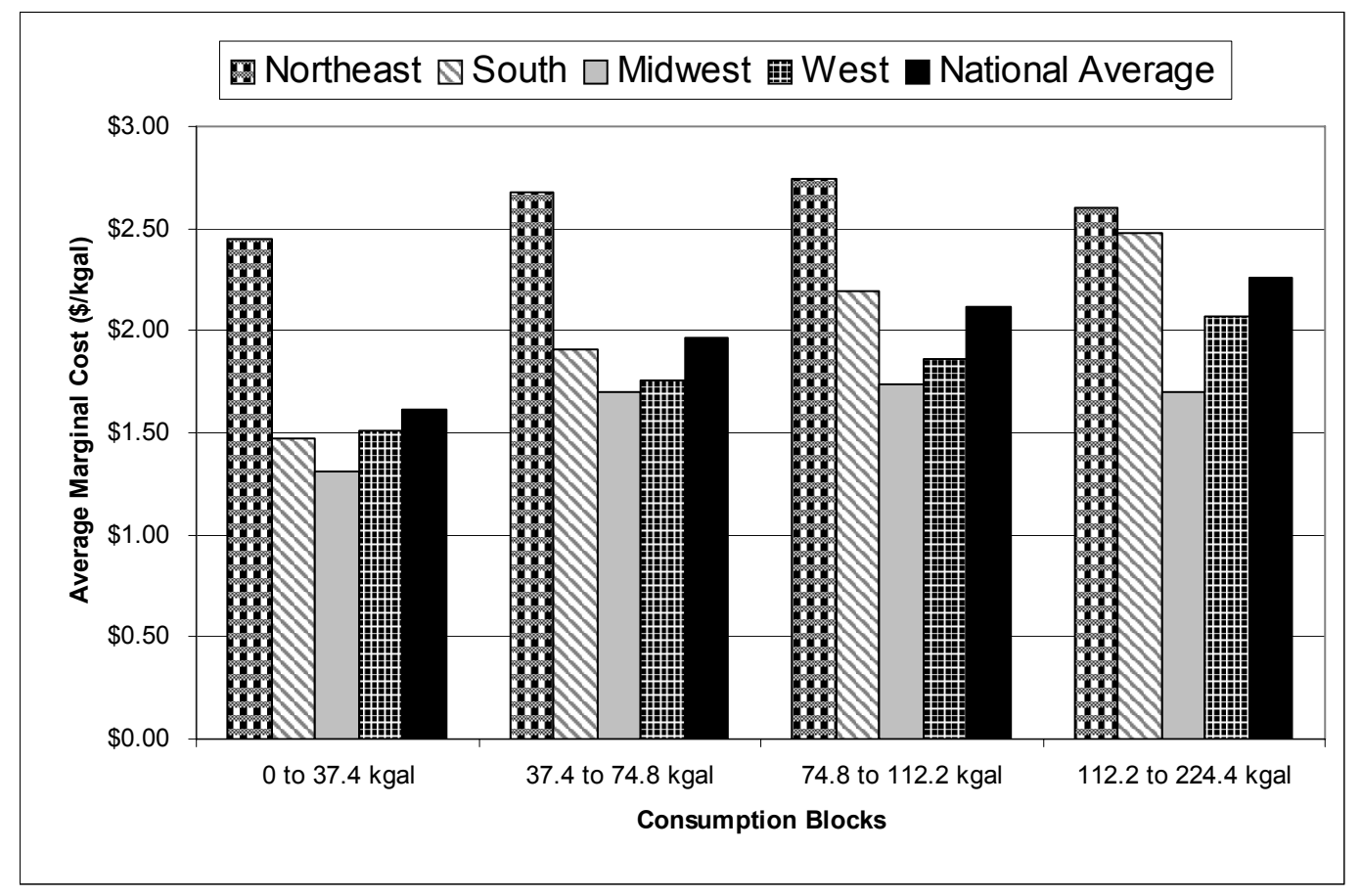

Figure 1A Marginal Rates of Water Blocks by Region from RFC 2004

Water and wastewater rates are rising faster than the rate of inflation. For example, from 1996 to 2004 the average water rate increased 39.5 percent, average wastewater rate increased 37.8 percent, the CPI (All Urban) increased 20.1 percent, and the CPI (Water and Sewerage Maintenance) increased 31.1 percent. On average, annual increases were 4.3 percent for water and 4.1 percent for wastewater, compared to 2.3 percent for the All Urban CPI and 3.7 percent for the CPI for water and sewerage maintenance. If trends in rates for water and wastewater rates continue, water-efficient products will become more valuable and more cost-effective. 


\section{INTRODUCTION}

To calculate the savings in water and wastewater costs achieved by water-efficient technologies or water conservation programs, one must know the marginal cost of the water and wastewater saved. Water and wastewater bills typically include a monthly fixed charge, which remains the same regardless of consumption, along with charges that change depending on the volume of water consumed or wastewater released to the sanitary sewer. The volume charge may be uniform (i.e., each unit may cost the same no matter how many units are consumed), or a block structure may assign different per-unit charges depending on total consumption. Block structures can be increasing (whereby the rate per unit increases as more units are consumed), decreasing (the rate decreases as consumption increases), or even increasing and then decreasing. Developing an accurate picture of the potential cost savings from water conservation requires knowing the cost of the last few units of water consumed or wastewater released, because those are the units that would be saved by increased water efficiency.

As detailed below, some data sets containing water and wastewater costs do not separate fixed costs from volume charges. Including fixed costs in the average cost per unit of water conserved produces an inaccurately high estimate of savings, because this fixed cost cannot be reduced by water conservation. Data sets that include separate information about volume charges often simply report the charge for a specified level of consumption (for residential consumption, typically about 7.5 to 11.2 kilo-gallons per month). Using this single value will give accurate results if the utility has a uniform volume charge, but may under- or overestimate the value of saving a unit of $7.5 \mathrm{kgals}$. ( $1 \mathrm{ccf}$ ) if the utility utilizes a block structure. The most accurate value of a unit saved can be obtained from data sets that contain enough information about the governing tariff to reconstruct the associated block structure and directly calculate the value of water saved for a given volume of water consumed or wastewater released.

This report describes the data we obtained on water and wastewater rates, our calculations of average water and wastewater rates, data gaps we identified, and other issues related to using the data to estimate cost savings that might accrue from water conservation programs.

\section{SEARCH METHODOLOGY}

Our goal was to identify any data set, national or regional, in which water and wastewater tariffs, rates, or monthly/bimonthly costs were compiled. Contacting individual water or wastewater agencies for specific rate information was beyond the scope of this study.

We identified data sets first by performing Internet searches using the keywords "water rates," "wastewater rates," "water tariffs," and "wastewater tariffs." We then examined the bibliographies of all data reports we found to check for references to other data sets. 


\section{DEFINITION OF TERMS}

This section includes definitions ${ }^{*}$ for some of the terms used in this report. Where appropriate, the units associated with a term are given following the term's definition.

Consumption: Consumption is the total integrated use of a commodity (water) during a billing period. Water consumption typically is measured in terms of hundreds of cubic feet or gallons. (gal.)

Block: A block is the range of consumption to which a particular consumption unit and rate belong.

Tariff: A tariff is the set of rules that establishes utility charges. Tariff also can refer to the legal document or regulation that contains this set of rules. A tariff is not a billing rate or charge, but rather a set of rules, or an algorithm, that is used to calculate a customer's bill (or cost).

$\underline{\text { Rate: }}$ The amount charged per unit of water or wastewater, generally expressed as dollars per 1000-gallon unit. (\$/kgal.)

Average rate: The average amount charged per unit of water consumed or wastewater released. The average rate is calculated by dividing the total charge by the total number of units consumed. (\$/kgal.)

Marginal rate: The amount paid for the last few units consumed, which are also the units that potentially could be saved by conservation. The marginal rate can be determined (or at least approximated) based on the block that contains the last unit, or alternatively by calculating the difference in bills pre- and post-conservation and dividing by the number of units conserved. (\$/kgal.)

Cost or charge (these terms are almost synonymous): The amount a customer is charged for water and/or wastewater services. (\$) The cost or charge can be subdivided into:

Fixed cost or service charge: An amount charged each billing period that does not change based on the amount of water consumed or wastewater released. (\$)

Variable cost or volume charge: An amount charged to the customer that is based on the amount of water consumed or wastewater released during the billing period.

Marginal cost: The cost of units saved by conservation. Marginal cost equals marginal rate multiplied by the number of units saved. (\$)

\footnotetext{
* Definitions are adapted from the Tariff Analysis Project, Environmental Energy Technologies Division, Lawrence Berkeley National Laboratory: http://tariffs.lbl.gov/notes/definitions.php
} 


\section{DATA SOURCES}

Below we describe the sources we found for water and wastewater rates. First, we identified two national data sets that contain information about both water and wastewater rates. The Raftelis/American Water Works Association (AWWA) survey questions 305 utilities of all sizes throughout the nation. In addition, Black and Veatch performed a more limited survey of water and wastewater rates in the 50 largest American cities. We also identified a national data set (from the National Association of Clean Water Agencies) that contains information about wastewater rates only. Another national data set (AWWA) contains information about water rates, but has had no data added since 1999 and was superseded by the Raftelis/AWWA survey. We also describe two studies of water and wastewater rates in California-one by Lawrence Berkeley National Laboratory, and the other by Black and Veatch.

\subsection{Raftelis/AWWA}

Raftelis et al. have published the Water and Wastewater Rate Survey biennially since 1996. The most recent survey, published in 2004, is hereafter referred to as RFC 2004. For RFC 2004, the American Water Works Association joined with Raftelis to expand the scope of the survey. Prior to that, the AWWA published its own survey (see Section 4.3).

The RFC 2004 survey includes data from 305 utilities in the United States, 12 in Canada, and 44 in other countries. Because we are concerned only with rates for water and wastewater in the United States, this discussion considers only the American utilities that were surveyed. Of those utilities, 159 provide both water and wastewater services; 107 provide water only; and 39 provide wastewater services only. Adding the utilities that provide both services to each of the other two categories gives us a sample that contains 266 utilities that provide water and 198 that provide wastewater services. The sample included at least one utility from each of the 50 states. California, with 27, had the most utilities sampled, followed by Florida, with 20. Although the sample is not large enough to represent every state accurately, it can be used to examine national and regional rates. RFC divides the data into four regions - the Northeast, South, Midwest, and West. Table 1 shows the number of utilities surveyed in each region. Based on their reported service populations, the water utilities included in the survey serve 34 percent of the American population; the wastewater utilities serve 28 percent of the population.

The RFC survey gives the South the greatest coverage, which the survey authors note may be because they reside in the South. Calculating values separately for each region, then taking an average of the four regions weighted by the population in each region, can compensate for the disproportionate coverage of the South. 
Table 1. Utilities Surveyed by Region in RFC 2004

\begin{tabular}{|l|c|}
\hline \multicolumn{1}{|c|}{ Region } & Number of Utilities Surveyed \\
\hline Northeast & 47 \\
\hline Midwest & 62 \\
\hline South & 114 \\
\hline West & 82 \\
\hline
\end{tabular}

Table 2 summarizes the various types of rate structures, for residential customers, included in RFC 2004. The map shows the distribution of utilities around the United States that are included in the RFC rate survey.

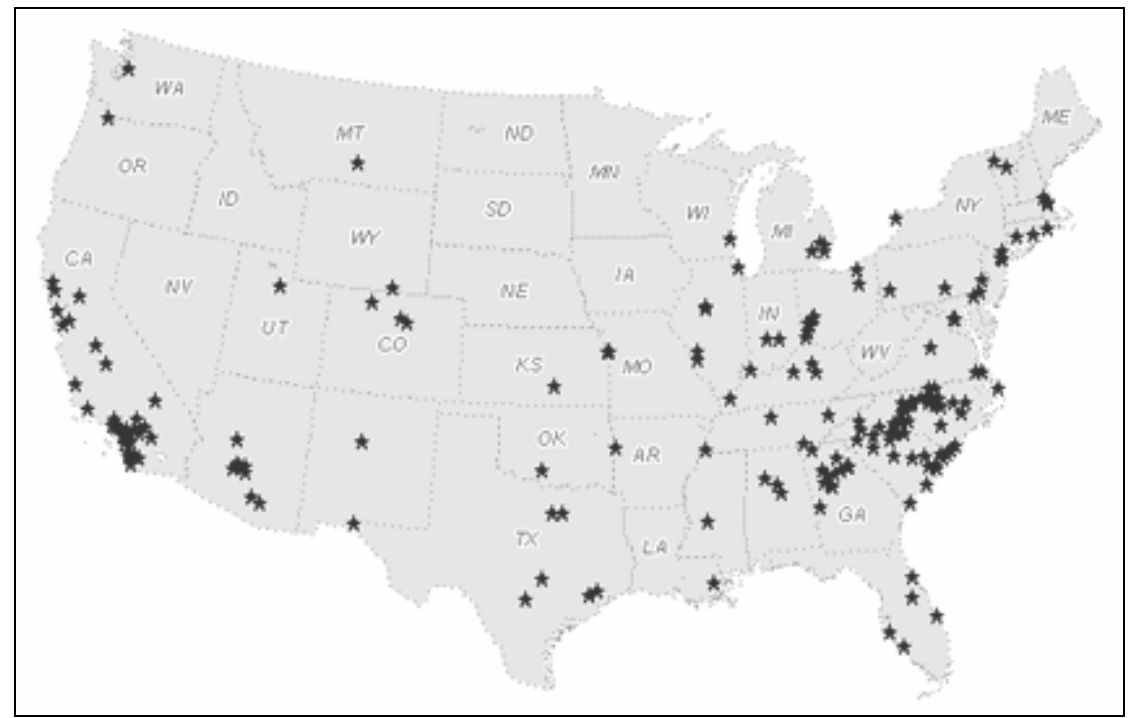

Figure 1 Distribution of water and wastewater utilities included in the Raftelis Financial Consultant rate survey

Table 2. Residential Rate Structures in RFC 2004

\begin{tabular}{|l|c|c|}
\hline Rate Structure Type & $\begin{array}{l}\text { Percent of Water } \\
\text { Utilities }\end{array}$ & $\begin{array}{l}\text { Percent of Wastewater } \\
\text { Utilities }\end{array}$ \\
\hline Flat & $5 \%$ & $18 \%$ \\
\hline Uniform & $33 \%$ & $59 \%$ \\
\hline Increasing Blocks & $32 \%$ & $9 \%$ \\
\hline Decreasing Blocks & $22 \%$ & $8 \%$ \\
\hline Increasing/Decreasing & $4 \%$ & $1 \%$ \\
\hline Not Reported & $4 \%$ & $7 \%$ \\
\hline
\end{tabular}

As shown in Table 2, only 5 percent of utilities charge a flat rate for water- that is, a fixed amount per billing cycle regardless of how much water is consumed. One-third apply a uniform rate, whereby the charge is the same for every 1000-gallon unit of water. About another one-third use an increasing block structure, whereby the cost per unit increases as consumption increases; 22 percent use a decreasing block structure, whereby 
the cost per unit decreases as consumption increases; 4 percent have a block structure that increases at first, then decreases; and 4 percent did not report a rate structure.

A larger percentage of wastewater providers than water providers use a flat (18 percent) or uniform (59 percent) rate for residential customers. About 17 percent use a block structure, almost equally divided between those that use increasing blocks and those that use decreasing blocks. Only 1 percent use block structures that increase and then decrease; 7 percent did not report a rate structure.

For residential customers having 5/8-inch meters (a common residential meter size), RFC 2004 reports the fixed service charge, volume charge, and total bill for five levels of monthly water consumption: $0 ; 3,740 ; 7,480 ; 11,220$; and 22,440 gallons $(0,5,10,15,30$ ccf). The reported volume charge is the total, not incremental, charge for each volume. The volume ranges most typical for the residential sector is the block 7480-11,220 gallons (10-15 ccf). For example, for a uniform rate of $\$ 2.00$ per kgals, the reported volume charge at 3,740 gallons (five times the consumption) would be $\$ 10.00$; for 7,480 gallons it would be $\$ 20.00$, or double the volume charge at 3,740 gallons.

\subsubsection{Calculation Methodology}

We used the reported charge for each of the five volumes to calculate a value that begins to approximate a marginal rate. We calculated incremental volume charges for levels of 3,$740 ; 7,480 ; 11,220$; and 22,440 gallons by subtracting the volume charge assigned to the next lowest level. We then divided the charge by the incremental unit of 748 gallons to calculate an average price per 748-gallon unit for four blocks: 0 to 3,750; 3,750 to 7,$500 ; 7,500$ to 11,250 ; and 11,220 to 22,440 gallons. If, for example, a utility reported a volume charge of $\$ 0$ for 0 gallons, $\$ 7.50$ for 3,750 gallons, and $\$ 17.50$ for 7,500 gallons, we calculated an incremental charge of $\$ 7.50-0=\$ 7.50$ for gallons 0 to 3,750 (units 0 to 5), then divided by $5-0$ units $=5$ units to obtain an average rate of $\$ 1.50$ per 750 gallon unit for the first 3,750 gal. We calculated an incremental charge of $\$ 17.50-\$ 7.50$ $=\$ 10.00$ for gallons 3,750 to 7,500 (units 5 to 10 ), then divided by $10-5$ units $=5$ units to obtain an average rate of $\$ 2.00$ per unit for the second 3,750 gallons.

Calculating rates using the RFC 2004 data should give us a fair approximation of true marginal rates. The calculations may not give the exact marginal rate, however, because the utility's block structure may not have the same breakpoints as used in RFC 2004. For example, if a utility stipulates blocks from 0 to 5,250 and 5,250 to 10,500 gallons, our calculated value for gallons 3,740 to 7,480 would be a weighted average of the utility's rate for its first and second blocks.

\subsubsection{Calculated Marginal Rates for Water}

Figure 2 shows our calculated rates for the four consumption blocks, separated into the four regions identified by RFC 2004. 


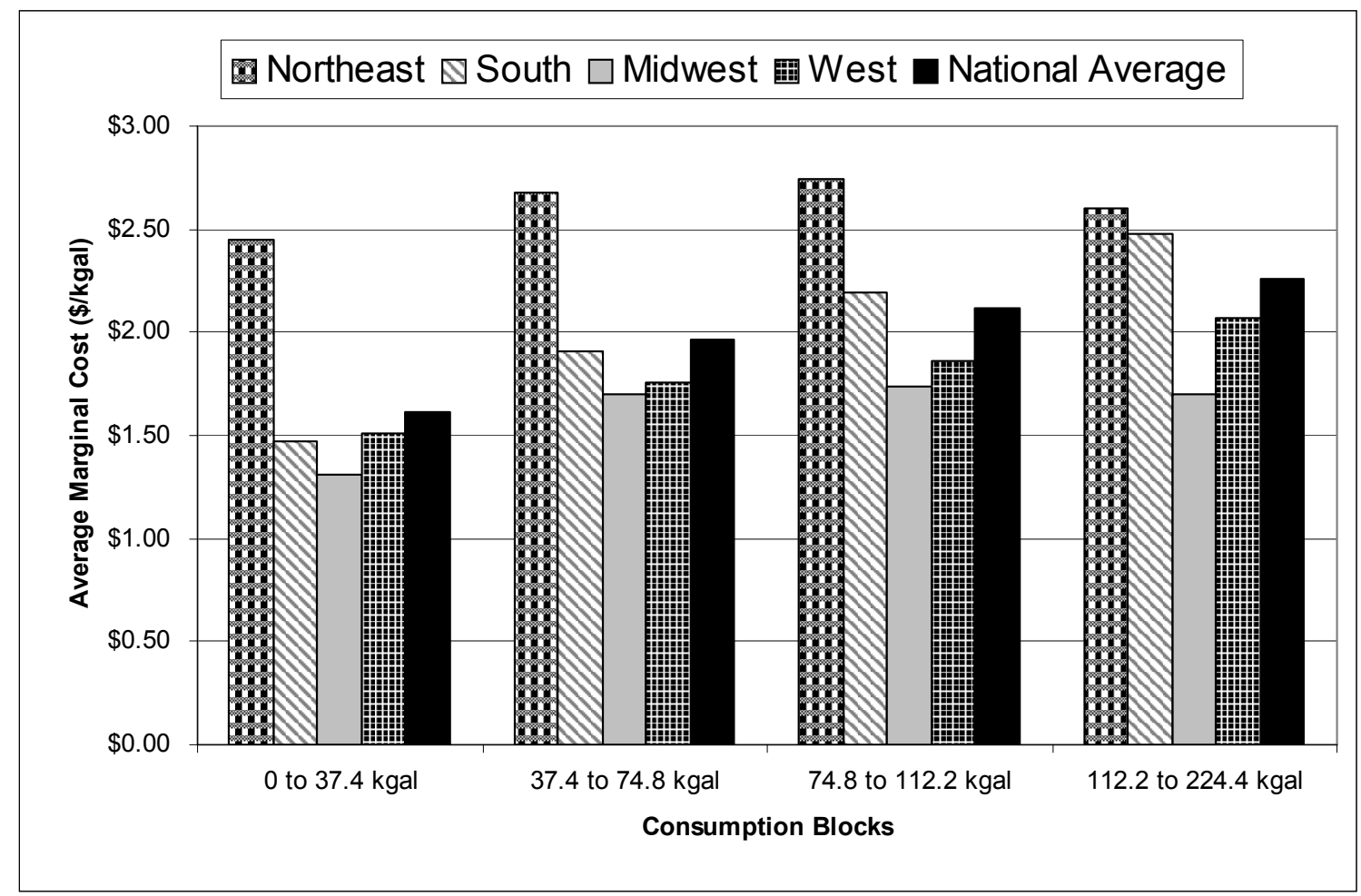

Figure 2 Marginal Rates of Water Blocks by Region from RFC 2004

As shown in Figure 2, rates are highest in the Northeast, particularly at low to moderate levels of water consumption. The lowest rates are found in the Midwest. Rates rise with consumption more rapidly in the South and West than in the Northeast and Midwest. In those latter two regions, average marginal rates decline slightly at the highest level of consumption.

\subsubsection{Calculated Marginal Rates for Wastewater}

Figure 3 shows the average marginal rates for wastewater blocks based on RFC 2004. These values were calculated as described above for water. 


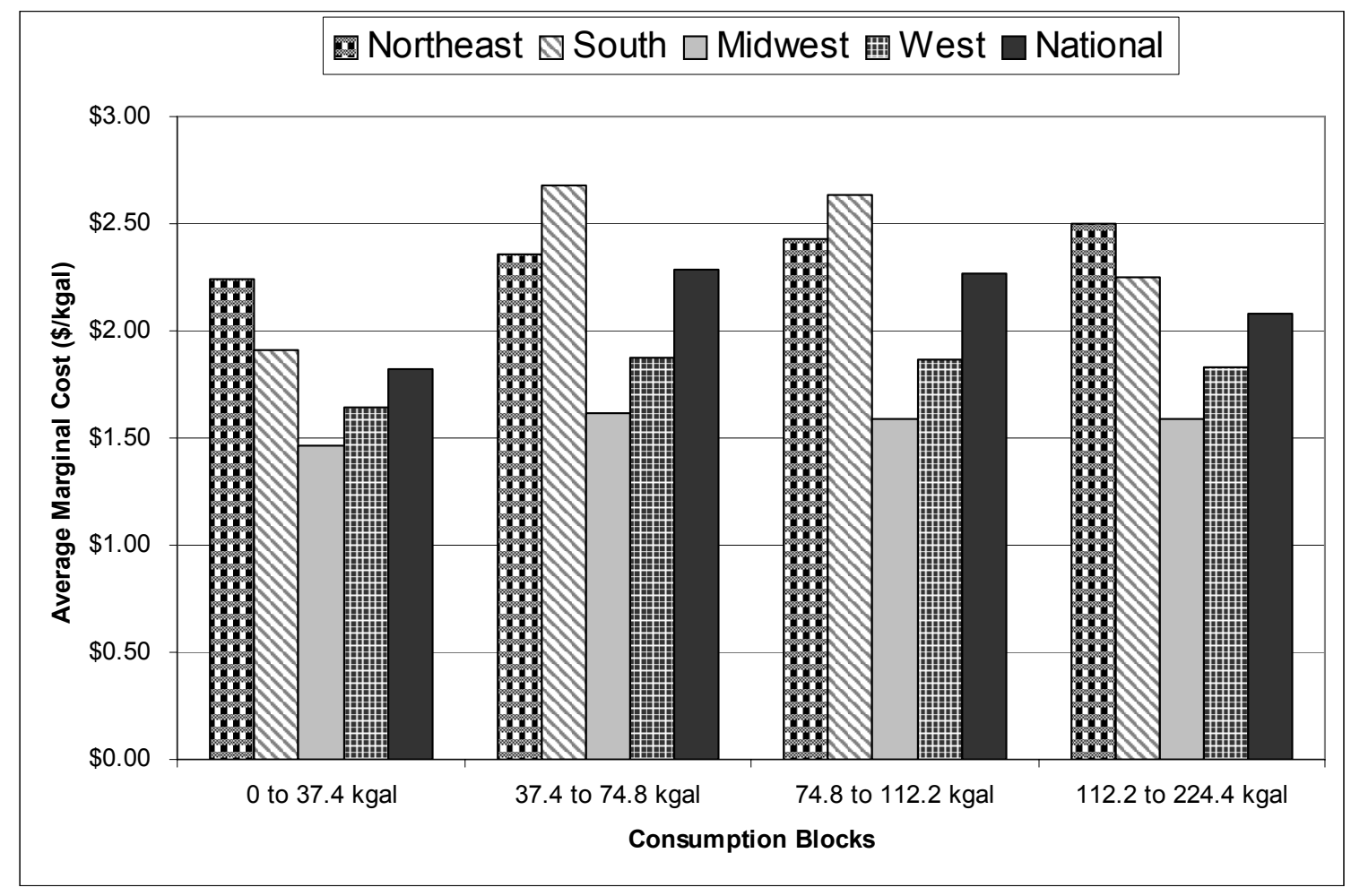

Figure 3 Marginal Rates of Wastewater Blocks by Region from RFC 2004

As with water rates, we can identify regional differences, this time finding higher rates, in the Northeast and South and lower rates in the Midwest and West. There appears somewhat less variation in rates based on wastewater discharge than there was based on water consumption, reflecting the fact that 59 percent of wastewater utilities report using a uniform rate, and 18 percent have a flat rate (effectively a uniform rate of $\$ 0$ per 1000 gallon unit). The somewhat lower rates seen for the highest usage block may be attributable in part to the fact that some wastewater utilities cap the volume charge - once the cap is exceeded, the rate for discharging additional wastewater is effectively $\$ 0$ per unit.

\subsubsection{Calculated Commercial and Industrial Marginal Rates for Water}

RFC 2004 also reports data on the larger meters typically used for commercial and industrial water connections: $5 / 8$-inch ${ }^{*}, 2$-inch, 4 -inch, and 8-inch meters. For commercial and industrial customers, RFC 2004 reports the fixed service charge, volume charge, and total bill for only one level of water consumption for each meter size. The rates calculated therefore are average, not marginal, rates. Table 3 shows the average water rates found in RFC 2004 for larger meters. Calculating wastewater rates for commercial and industrial customers is complicated by the fact that often the charges depend on factors in addition to volume. For example, sometimes there is a higher charge for wastewater that has a high biological oxygen demand.

\footnotetext{
* RFC 2004 distinguishes between a 5/8-inch meter for a residential customer and a 5/8-inch meter for a "non-manufacturing" customer.
} 
Table 3. Average Water Cost for Non-Residential Customers, RFC 2004

\begin{tabular}{|l|r|r|r|r|}
\hline Region & $\begin{array}{c}\text { Non-Manufacturing } \\
\text { 5/8-inch } \\
(\$ / \mathrm{kgal} \text { ) }\end{array}$ & $\begin{array}{c}\text { Commercial } \\
\text { 2-inch } \\
(\$ / \mathrm{kgal} .)\end{array}$ & $\begin{array}{c}\text { Industrial } \\
\text { 4-inch } \\
(\$ / \mathrm{kgal} .)\end{array}$ & $\begin{array}{c}\text { Industrial } \\
\text { 8-inch } \\
(\$ / \mathrm{kgal} .)\end{array}$ \\
\hline Midwest & $\$ 1.36$ & $\$ 1.24$ & $\$ 1.03$ & $\$ 0.99$ \\
\hline Northeast & $\$ 2.42$ & $\$ 0.64$ & $\$ 1.93$ & $\$ 1.87$ \\
\hline South & $\$ 1.86$ & $\$ 1.91$ & $\$ 1.74$ & $\$ 0.37$ \\
\hline West & $\$ 1.84$ & $\$ 1.78$ & $\$ 1.79$ & $\$ 1.75$ \\
\hline Total & $\$ 1.87$ & $\$ 1.78$ & $\$ 1.67$ & $\$ 1.63$ \\
\hline
\end{tabular}

\subsection{Black and Veatch National Survey}

The consulting firm of Black and Veatch $(\mathrm{B} \& \mathrm{~V})$ periodically publishes a report on the average monthly costs of water and wastewater services (fixed plus volume charges) for the 50 largest cities in the United States. The most recent survey, for 2005, reports "typical" monthly water and wastewater bills for the 50 cities. For residential customers, total costs are reported for two levels of consumption: 7,500 and 15,000 gallons.

\subsubsection{Calculation Methodology}

Although the values reported represent total costs, including fixed monthly charges, one can estimate each city's volume charge by subtracting a 7,480-gal. bill from a 15,000gal., then dividing by 10 to find the average cost per 748-gallon unit for gallons 7,480 through 15,000 . Having monthly residential bills for only two different volume levels enables us to calculate an average rate.

\subsubsection{Calculated Average Rates}

Table 4 shows the rates for water and wastewater calculated for the 50 cities covered in the B\&V survey.

Table 4. Water and Wastewater Rates from B\&V National Survey

\begin{tabular}{|l|r|r|}
\hline \multicolumn{1}{|c|}{ City } & \multicolumn{1}{c|}{$\begin{array}{c}\text { Water } \\
\text { (\$/ kgal. })\end{array}$} & $\begin{array}{c}\text { Wastewater } \\
\text { (\$/kgal. })\end{array}$ \\
\hline Albuquerque & $\$ 1.64$ & $\$ 1.10$ \\
\hline Atlanta & $\$ 3.60$ & $\$ 8.62$ \\
\hline Austin & $\$ 3.52$ & $\$ 5.71$ \\
\hline Baltimore & $\$ 2.14$ & $\$ 3.29$ \\
\hline Boston & $\$ 4.02$ & $\$ 5.43$ \\
\hline Charlotte & $\$ 2.62$ & $\$ 2.95$ \\
\hline Chicago & $\$ 1.30$ & $\$ 1.08$ \\
\hline Cleveland & $\$ 2.49$ & $\$ 4.61$ \\
\hline
\end{tabular}




\begin{tabular}{|c|c|c|}
\hline City & $\begin{array}{c}\text { Water } \\
\text { (\$/kgal. })\end{array}$ & $\begin{array}{c}\text { Wastewater } \\
(\$ / \text { kgal. })\end{array}$ \\
\hline Colorado Springs & $\$ 3.06$ & $\$ 2.29$ \\
\hline Columbus & $\$ 1.83$ & $\$ 2.87$ \\
\hline Dallas & $\$ 2.49$ & $\$ 0.07$ \\
\hline Denver & $\$ 1.90$ & $\$ 1.83$ \\
\hline Detroit & $\$ 1.87$ & $\$ 2.75$ \\
\hline El Paso & $\$ 2.41$ & $\$ 1.52$ \\
\hline Fort Worth & $\$ 2.95$ & $\$ 1.68$ \\
\hline Fresno & $\$ 0.61$ & \\
\hline Honolulu & $\$ 2.25$ & $\$ 1.08$ \\
\hline Houston & $\$ 3.42$ & $\$ 3.49$ \\
\hline Indianapolis & $\$ 1.93$ & $\$ 1.34$ \\
\hline Jacksonville & $\$ 1.18$ & $\$ 3.93$ \\
\hline Kansas City & $\$ 2.53$ & $\$ 2.11$ \\
\hline Las Vegas & $\$ 1.64$ & \\
\hline Long Beach & $\$ 2.70$ & $\$ 0.20$ \\
\hline Los Angeles & $\$ 3.17$ & $\$ 3.22$ \\
\hline Memphis & $\$ 1.52$ & $\$ 0.88$ \\
\hline Mesa & $\$ 2.22$ & $\$ 1.59$ \\
\hline Miami & $\$ 2.46$ & $\$ 3.11$ \\
\hline Milwaukee & $\$ 1.58$ & $\$ 2.43$ \\
\hline Minneapolis & $\$ 3.34$ & $\$ 2.67$ \\
\hline Nashville & $\$ 3.56$ & $\$ 6.51$ \\
\hline New Orleans & $\$ 2.42$ & $\$ 3.60$ \\
\hline New York & $\$ 2.21$ & $\$ 3.50$ \\
\hline Oakland & $\$ 2.89$ & \\
\hline Oklahoma City & $\$ 1.74$ & $\$ 2.49$ \\
\hline Omaha & $\$ 1.23$ & $\$ 0.82$ \\
\hline Philadelphia & $\$ 2.70$ & $\$ 2.19$ \\
\hline Phoenix & $\$ 2.50$ & $\$ 1.98$ \\
\hline Portland & $\$ 2.58$ & $\$ 7.09$ \\
\hline \multicolumn{3}{|l|}{ Sacramento } \\
\hline San Antonio & $\$ 3.03$ & $\$ 1.95$ \\
\hline San Diego & $\$ 2.86$ & $\$ 1.72$ \\
\hline San Francisco & $\$ 2.67$ & $\$ 8.74$ \\
\hline San Jose & $\$ 2.42$ & \\
\hline Seattle & $\$ 4.21$ & $\$ 8.80$ \\
\hline St. Louis & $\$ 1.71$ & $\$ 2.42$ \\
\hline Tucson & $\$ 3.15$ & $\$ 1.46$ \\
\hline Tulsa & $\$ 1.99$ & $\$ 2.65$ \\
\hline Virginia Beach & $\$ 3.80$ & $\$ 2.03$ \\
\hline Washington & $\$ 2.77$ & $\$ 4.06$ \\
\hline
\end{tabular}




\begin{tabular}{|l|r|r|}
\hline \multicolumn{1}{|c|}{ City } & \multicolumn{1}{c|}{$\begin{array}{c}\text { Water } \\
\text { (\$/ kgal. })\end{array}$} & $\begin{array}{c}\text { Wastewater } \\
\text { (\$/kgal. })\end{array}$ \\
\hline Wichita & $\$ 2.67$ & $\$ 1.55$ \\
\hline $\begin{array}{l}\text { Median } \\
\text { (unweighted) }\end{array}$ & $\$ 2.49$ & $\$ 2.43$ \\
\hline Maximum & $\$ 4.21$ & $\$ 8.80$ \\
\hline $\begin{array}{l}\text { Non-zero } \\
\text { minimum }\end{array}$ & $\$ 0.61$ & $\$ 1.18$ \\
\hline
\end{tabular}

As shown in Table 4, rates for water range from a low of $\$ 0$ per kgal unit (non-zero minimum of $\$ 0.61$ per unit) to a high of $\$ 4.21$ per unit, and rates for wastewater range from $\$ 0$ per kgal unit (non-zero minimum of $\$ 1.10$ per unit) to $\$ 8.80$ per unit. The mean is $\$ 2.48$ per kgal unit for water and $\$ 3.01$ per kgal unit for wastewater; the median is $\$ 2.49$ per unit for water and $\$ 2.43$ per unit for wastewater.

\subsubsection{Calculated Commercial and Industrial Rates for Water}

Black and Veatch's national survey of the 50 largest cities includes larger meter sizes. $\mathrm{B} \& \mathrm{~V}$, however, provides only the total monthly bill for one stipulated level of consumption; neither do they separate service from volume charges. Because they do not report the total charge for more than one volume, we cannot subtract out fixed costs, as we did for residential charges.

\subsection{American Water Works Association}

The American Water Works Association (AWWA) collected and published operating data from water utilities nationwide for more than a century. AWWA categorized the data into six areas:

- Finances

- Revenue

- Distribution Systems

- Treatment Processes

- Water Quality

- Demographics

In 1996 and 1999, AWWA placed the data it collected into databases called WaterStats. These databases include information about rate structures and charges. Because AWWA members are water providers, the database includes information on water only, not wastewater.

The 1999 survey includes all the information needed to reconstruct the exact charge for the last unit of water consumed (or potentially saved by water efficiency). For those 
utilities that use block rates, the database includes the upper and lower limits of consumption for each block, as well as the rate for each block.

This level of detail was reduced, however, when AWWA joined Raftelis in performing the 2004 survey (see Section 4.1). The parameters were changed most likely to maintain consistency with the format of previous Raftelis surveys. As described above, the RFC 2004 data provide some detail about rate versus consumption for residential customers, but in many cases the rates calculated from RFC 2004 data will be averages of two or more blocks.

Because the WaterStats database has been superseded by the Raftelis/AWWA survey, and because the 1999 data are now somewhat outdated, we will not describe the AWWA database further.

\subsection{AMSA/NACWA}

The National Association of Clean Water Agencies (NACWA, formerly the Association of Metropolitan Sewerage Agencies [AMSA]) has performed and published a financial survey of member agencies every three years since 1981. Members of the NACWA are wastewater services providers, so the survey covers wastewater rates only. For the most recent (2005) survey, completed surveys were returned by 141 agencies in 38 states and the District of Columbia, representing 47 percent of the NACWA membership.

\subsubsection{Survey Data}

The NACWA survey asks about the utility's rate structure (flat vs. metered, uniform rate vs. ascending or descending blocks); fixed charges; and volume charges (if any). In some cases survey responses were incomplete; for example, some agencies reported using volume charges, but did not delineate those charges.

\subsubsection{Calculated Marginal Rates}

For those entities that provided complete information, volume charges ranged from a low of $\$ 0.61$ to a high of $\$ 6.34$ per kilo-gallon unit. The average, weighted by number of retail accounts, was $\$ 2.41$ per unit when including utilities that apply flat rates (effectively a volume charge of $\$ 0$ per unit), and $\$ 2.71$ when excluding utilities that apply flat rates. The value $\$ 2.41$ per kilo-gallon unit derived from this survey is similar to the value calculated for the middle two blocks (3,750 to 7,500 and 7,500 to 11,250 gal.) from RFC 2004 wastewater rates, which is \$2.27 per kilo-gallon unit (see Figure 3). The lowest and highest blocks of the RFC 2004 data may be lower than those from the AMSA/NACWA survey because of minimum and/or maximum consumption charges. The NACWA includes some information about industrial rates; however, it is not clear what meter size is associated with those rates. Non-residential wastewater charges are complicated by the fact that they often are based on factors in addition to volume, such as biological oxygen demand of the released water and other strength/concentration parameters. 


\subsection{California Surveys}

Two surveys performed in one state provide data that serves as a good confirmation of and comparison to results from the national surveys discussed previously.

\subsubsection{LBNL Study}

In 2005, the California Energy Commission asked Lawrence Berkeley National Laboratory (LBNL) to collect information on water and wastewater tariffs for areas of high residential growth in California. These data, compiled by Fisher and Lutz (2006), will support the next update of California's Title 24, which establishes energy-efficiency criteria that must be met by new residential construction in the state. Because some of the efficiency measures save hot water, they save water as well as energy. The LBNL data, like the 1999 AWWA survey, include all the information needed to reconstruct water and wastewater tariffs for the subject utilities (for block rates, data include the upper and lower consumption limits for each block).

The LBNL database currently includes rate information for 75 companies or governmental agencies: 41 providers of both water and wastewater services, 21 providers of water services only, and 13 providers of wastewater services only. Adding those that provide both water and wastewater services to each of the other two categories results in 62 that provide water service and 54 that provide wastewater services.

\section{Marginal Water Rates from LBNL Survey}

Only 6 percent of water utilities in the LBNL California sample use a flat rate. Another 45 percent use a uniform volume charge. The remaining water utilities use block rates, nearly all of which are increasing.

Figure 4 shows the distribution of rates found in the LBNL study for the $11^{\text {th }} 750$-gallon unit of water consumed per month. The range of 7,500 to 9,000 gallons per month is fairly typical for residential consumption, so this value approximates the cost savings that would accrue from conserving 750 gallons of water per month. 
Figure 3. Number of Unique Tariffs Having a Given Marginal Rate

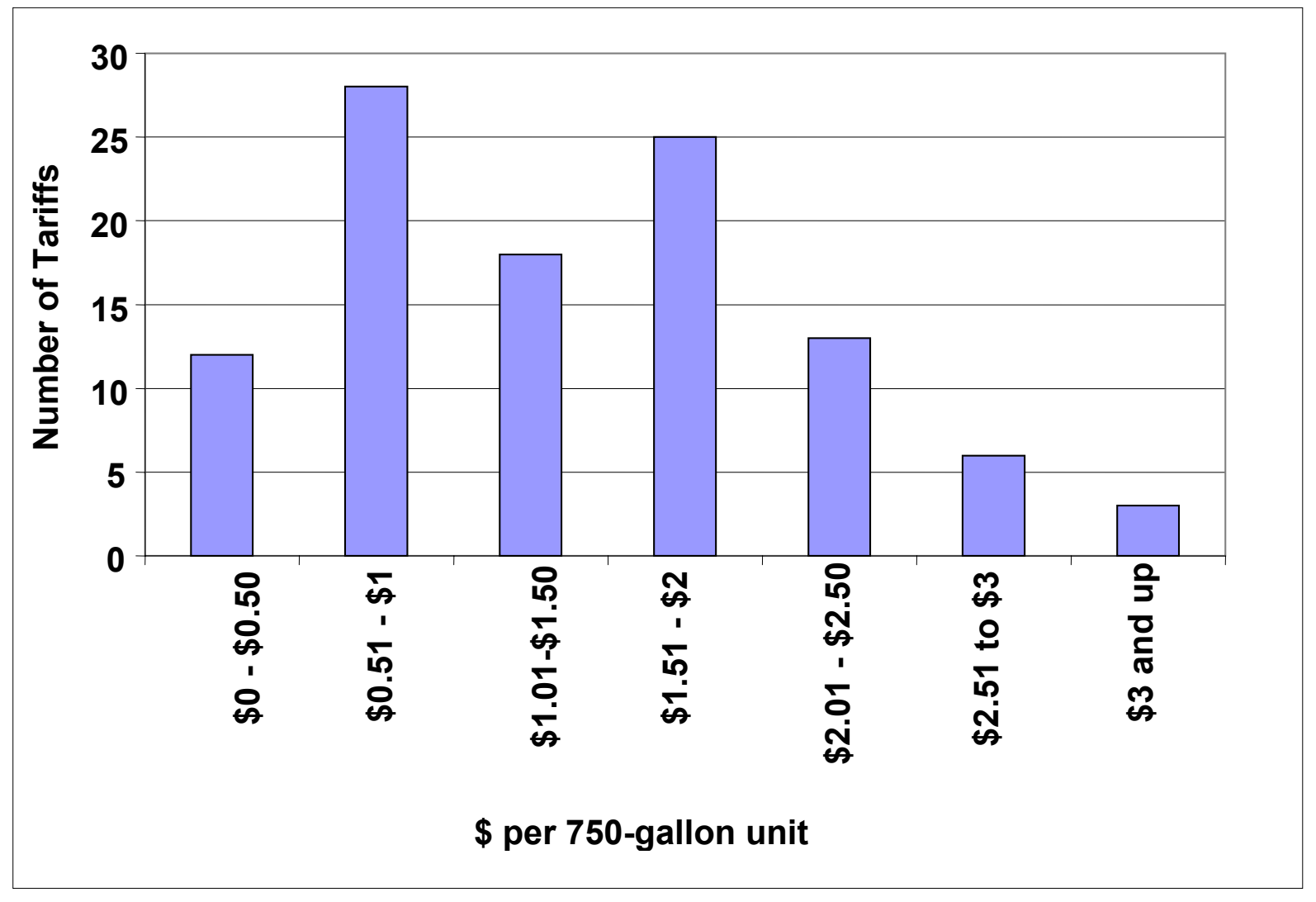

The average cost for the $11^{\text {th }} 750$-gallon $(1 \mathrm{ccf})$ unit used, including flat rates, was $\$ 1.40$. Excluding flat rates, the average cost for the $11^{\text {th }}$ unit was $\$ 2.03 / \mathrm{kgal}$. ( $\$ 1.52 / 750$ gallon). Of the non-zero values, the lowest was $\$ 0.32$ per $11^{\text {th }}$ unit, and the highest $\$ 7.06$ per $11^{\text {th }}$ unit.

\section{Marginal Wastewater Rates from LBNL Survey}

The LBNL study found that 41 of 54 service providers (76 percent of the sample) apply flat rates for wastewater (rates that are independent of water consumption). Of the remaining 13, 6 base their rates on metered water consumption during a base period the previous winter. That is, rates are adjusted once a year based on the previous year's water consumption; they then remain fixed for the following 12 months. The remaining 7 base their rates on monthly metered water consumption. Sometimes the utilities apply a multiplier (typically 0.75 to 0.90 ) to estimate the fraction of water (whether based on the previous winter or monthly metered use) that is released to the sewer. For data from utilities that apply such a multiplier, Fisher and Lutz (2006) multiplied the nominal rate per kilo-gallons times this multiplier to calculate the actual charge per kilo-gallon unit, which then was entered into the database. For example, if a utility applies a nominal sewer charge of $\$ 2.67$ per kilo-gallon unit, and multiplies metered water use by 0.90 to estimate sewer use, they multiplied $\$ 2.00$ by 0.90 , then entered $\$ 2.41$ per unit into the database, because that is the effective charge per kilo-gallon unit of metered water use. 
Of the 13 companies that base sewer rates on water use, 2 define only broad categories of water consumption. For example, some cities charge $\$ 10$ per month for users whose estimated sewer use is 0 to 3,750 gallons, $\$ 15$ per month for 4,500 to 7,500 gallons, and $\$ 20$ per month for 8,250 or more gallons. LBNL modeled this approach by considering the $\$ 10$ charge for the lowest usage category as a fixed monthly cost (all users pay at least $\$ 10)$. The consumption charges were entered as $\$ 0$ per 750 -gallon unit for the first 3,750 gal.; $\$ 5$ per unit when consumption reaches 4,500 gallons (the additional cost incurred at 4,500 gallons bumps the consumer up to the next category); $\$ 0$ for 5,250 through 7,500 gallons; $\$ 5$ when reaching 8,250 gallons; and \$0 for every gallon beyond 8,250 .

There were 17 unique tariffs for the 13 companies that impose volume charges ( 4 companies had different rates for multifamily residences than for single-family). LBNL calculated the charge for the $8,250^{\text {th }}$ gallon released in a month. Four of the 17 tariffs had a marginal rate of $\$ 0$. The lowest non-zero value was $\$ 0.47$ per 750 -gallon unit; the highest was $\$ 11.54$ per unit. The highest value was from one of two utilities that base rates on categories of usage, as described above. Because the $8,250^{\text {th }}$ gallon marks the transition from one category to the next highest, the marginal rate for that one unit is quite high.

The average marginal rate per 750-gallon unit of wastewater, including $\$ 0$ for all 41 of the flat-rate utilities, was $\$ 0.74$ per unit. The average of the non-zero values was $\$ 3.23$ per unit.

\subsubsection{Black and Veatch Surveys}

Black and Veatch (B\&V) has published water rate surveys for California for 1995, 1997, 1999, 2001, 2003 and 2006, and wastewater rate surveys for 2000, 2002, and 2004. The B\&V water rate surveys collect data on a consumer's total monthly bill for 11,250 gallons per month of water consumption. The earlier surveys reported only a monthly total, without separating fixed monthly charges from any volume charges. In the 2003 and 2006 surveys, fixed and volume costs were reported separately for those utilities that apply a volume charge. (In 2003, 8.9 percent of the utilities surveyed used a flat rate; in 2006, 6.4 percent did so).

The B\&V wastewater surveys collect data on a consumer's total average monthly bill for 9,000 gallons per month. Fixed and volume charges are not separated. Most utilities surveyed (88 percent in 2004) charge a flat monthly rate for wastewater services that does not reflect water consumption.

\section{Calculated Water Rates}

In the 2006 survey, the average monthly water bill from all utility companies was $\$ 36.39$. For those that apply volume charges, the average fixed monthly charge was $\$ 12.10$, and the average volume charge was $\$ 22.78$. Because those values are for 11,220 gallons of water consumed per month, we can calculate an average rate of $\$ 1.52$ per 750 -gallon unit ( $\$ 22.78$ divided by 15 ). Because many utilities (43 percent in the B\&V survey) use tiered 
rate structures, however, the marginal cost savings of, for example, one 750-gallon unit per month may not equal the average rate per unit.

\section{Calculated Commercial and Industrial Rates for Water}

B\&V's California reports do not include commercial- or industrial-size meter connections.

\section{SUMMARY OF FINDINGS}

In seeking current information on water and wastewater rates, we found three national data sets and one state data set: RFC 2004, the Black and Veatch national survey, AMSA/NACWA, and the Black and Veatch California survey. In addition, LBNL conducted a tariff analysis for California that included a compilation of data sources. Since 1999, AWWA itself has stopped providing water rate information for public purchase, so we excluded their older data sets from consideration. The following sections summarize our calculations of average national-rates for water and wastewater services based on the data we acquired and analyzed. Regional variations also are discussed.

\subsection{Average Rates for Water and Wastewater}

Table 5 summarizes average national rates for water and wastewater volumes in the three national surveys we evaluated for this report. Where rates where calculated for more than one block of volumes, we report the value for the block that begins at 7,500 gallons, a fairly typical value for monthly residential water consumption. The average rates derived from the RFC 2004 and NACWA surveys were weighted by the number of each utility's residential accounts. Because this information was unavailable for the B\&V survey, we report the unweighted average for that survey.

We recommend that analyses of the rate-saving potential of water-saving technologies utilize values derived from RFC 2004, the most detailed and comprehensive of the surveys. The averages obtained from the other two national surveys are fairly close to those obtained from the RFC 2004 survey.

Table 5. Summary of National Average Rates for Water and Wastewater

\begin{tabular}{|l|c|c|c|c|}
\hline \multicolumn{1}{|c|}{ Survey } & Year & Block (if applicable) & $\begin{array}{c}\text { Water } \\
(\$ / \text { kgal. })\end{array}$ & $\begin{array}{c}\text { Wastewater } \\
(\$ / \text { kgal. })\end{array}$ \\
\hline RFC 2004 & 2004 & $7.5-11.2 \mathrm{kgal}$. & $\$ 2.13$ & $\$ 2.27$ \\
\hline B\&V National & 2005 & $7.5-15.0 \mathrm{kgal}$. & $\$ 2.43$ & $\$ 2.71$ \\
\hline NACWA & 2005 & NA & NA & $\$ 2.43$ \\
\hline
\end{tabular}

\subsection{Regional Variations}

The RFC data, as summarized in Figures 1 and 2, clearly show regional variations in rates and rate structures. For example, both the RFC and NACWA surveys find that about 20 percent of wastewater service providers use a flat rate, whereas both the LBNL and 
$\mathrm{B} \& \mathrm{~V}$ studies of California utilities found closer to 80 percent using a flat rate. Data for California utilities in the NACWA survey reveal the same situation. Of the 17 California wastewater utilities in the NACWA database, 12 report using flat rates, 3 use metered rates, and the other two do not report their rate structure.

The two studies of California rates reveal significant regional variation even within the state. Figure 3 illustrates the broad range of water rates found in the LBNL California study.

\section{PAST AND PROJECTED TRENDS IN RATES}

Where trend data are available, they generally show that, at least in the past decade, rates for water and wastewater have increased faster than the rate of inflation.

As shown in Table 6, for example, NACWA found that, for the 59 respondents common to both its 1990 and 2005 surveys, the average residential rate for wastewater services increased 30.9 percent between surveys, whereas the Consumer Price Index (CPI) increased 24.3 percent during that same period. The CPI for water and sewer maintenance, $38.6 \%$, increased more than both the CPI (All Urban) and the average Residential Charge. Before 2002, this finding is consistent for shorter periods of time as well, as also shown in Table 6. However, after 2002, the CPI for water and sewerage maintenance grows more quickly than the average residential charge.

Table 6. Increases in Residential Wastewater Charges Compared to CPI

\begin{tabular}{|l|c|c|c|c|}
\hline & $\begin{array}{l}1996- \\
1999\end{array}$ & $\begin{array}{l}1999- \\
2002\end{array}$ & $\begin{array}{l}2002- \\
2005\end{array}$ & $\begin{array}{l}1996- \\
2005\end{array}$ \\
\hline Common Entities Responding & 68 & 68 & 83 & 59 \\
\hline Change in Average Residential Charge & $+9.7 \%$ & $+13.1 \%$ & $+14.8 \%$ & $+30.9 \%$ \\
\hline $\begin{array}{l}\text { Change in Consumer Price Index (CPI), } \\
\text { All Urban }\end{array}$ & $+6.2 \%$ & $+8.0 \%$ & $+8.4 \%$ & $+24.3 \%$ \\
\hline $\begin{array}{l}\text { Change in CPI for water and sewerage } \\
\text { maintenance }\end{array}$ & $+8.6 \%$ & $+9.2 \%$ & $+16.9 \%$ & $+38.6 \%$ \\
\hline
\end{tabular}

Source: NACWA 2005, Table C.9-3., , Bureau of Labor Statistics

(http://www.bls.gov/cpi/cpisaqanda.htm)

In addition to its more comprehensive survey, the NACWA also performs an annual survey of percent changes in rates for sewer service, which is called the NACWA Service Charge index. This survey reveals trends in wastewater rate increases that are analogous to water rate trends.

A similar tendency can be seen in the RFC data. Table 7 summarizes the percent increase in water and wastewater charges between biennial surveys compared to increases in the CPIs for the same time intervals. From 1996 to 2004 the average water rate increased 39.5 percent, and the average wastewater rate increased 37.8 percent, while the All Urban CPI increased 20.1 percent, and the CPI for water and sewerage maintenance increased 
31.1 percent. On average, annual increases were 4.3 percent for water and 4.1 percent for wastewater, compared to 2.3 percent for the All Urban CPI and 3.7 percent for the CPI for water and sewerage maintenance.

Table 7. Increases in Rates and CPI since Previous RFC Surveys

\begin{tabular}{|l|c|c|c|c|}
\hline Year & 1998 & 2000 & 2002 & 2004 \\
\hline Water & $12.3 \%$ & $6.5 \%$ & $8.8 \%$ & $7.2 \%$ \\
\hline Wastewater & $3.5 \%$ & $10.1 \%$ & $7.9 \%$ & $12.1 \%$ \\
\hline $\begin{array}{l}\text { CPI - All } \\
\text { Urban }\end{array}$ & $4.7 \%$ & $4.5 \%$ & $4.9 \%$ & $4.6 \%$ \\
\hline $\begin{array}{l}\text { CPIfor water } \\
\text { and sewerage } \\
\text { maintenance }\end{array}$ & $6.3 \%$ & $11.2 \%$ & $18.6 \%$ & $31.1 \%$ \\
\hline
\end{tabular}

Source: RFC 2004, Bureau of Labor Statistics (http://www.bls.gov/cpi/cpisaqanda.htm)

Black and Veatch find this same trend in their California surveys, as shown in Table 8 for monthly water charges and Table 9 for monthly wastewater charges.

Table 8. Percent Changes in Water Rates and CPI, B\&V California Study

\begin{tabular}{|l|c|c|c|c|c|c|c|}
\hline $\begin{array}{l}\text { Time } \\
\text { Interval }\end{array}$ & $1991-$ & $1993-$ & $1995-$ & $1997-$ & $1999-$ & $2001-$ & $2003-$ \\
209 & 1995 & 1997 & 1999 & 2001 & 2003 & 2006 \\
\hline Water Rate & $10.0 \%$ & $10.3 \%$ & $6.6 \%$ & $4.9 \%$ & $6.0 \%$ & $5.8 \%$ & $20.0 \%$ \\
\hline $\begin{array}{l}\text { CPI, All } \\
\text { Urban }\end{array}$ & $6.1 \%$ & $5.5 \%$ & $5.3 \%$ & $3.8 \%$ & $6.3 \%$ & $3.9 \%$ & $14.7 \%$ \\
\hline $\begin{array}{l}\text { CPIfor } \\
\text { water and } \\
\text { sewerage } \\
\text { maintenance }\end{array}$ & $12.6 \%$ & $8.3 \%$ & $6.9 \%$ & $5.7 \%$ & $5.7 \%$ & $7.3 \%$ & $16.8 \%$ \\
\hline
\end{tabular}

Source: B\&V 2006, Bureau of Labor Statistics (http://www.bls.gov/cpi/cpisaqanda.htm)

Table 9. Percent Changes in Wastewater Rates and CPI, B\&V California Study

\begin{tabular}{|l|c|c|c|c|c|c|}
\hline Time Interval & $\begin{array}{l}1992- \\
1994\end{array}$ & $\begin{array}{l}1994- \\
1996\end{array}$ & $\begin{array}{l}1996- \\
1998\end{array}$ & $\begin{array}{l}1998- \\
2000\end{array}$ & $\begin{array}{l}2000- \\
2002\end{array}$ & $\begin{array}{l}2002- \\
2004\end{array}$ \\
\hline Wastewater Rate & $5.3 \%$ & $8.7 \%$ & $5.7 \%$ & $3.4 \%$ & $7.9 \%$ & $8.9 \%$ \\
\hline CPI-All Urban & $5.6 \%$ & $5.9 \%$ & $3.9 \%$ & $5.6 \%$ & $4.5 \%$ & $2.5 \%$ \\
\hline $\begin{array}{l}\text { CPIfor water and } \\
\text { sewerage } \\
\text { maintenance }\end{array}$ & $10.7 \%$ & $7.3 \%$ & $6.3 \%$ & $4.7 \%$ & $6.6 \%$ & $10.6 \%$ \\
\hline
\end{tabular}

Source: B\&V 2004, Figure 2, Bureau of Labor Statistics (http://www.bls.gov/cpi/cpisaqanda.htm)

$\mathrm{B} \& \mathrm{~V}$ found that between 1991 and 2006, the average water charge increased 83 percent in California, compared to a 55-percent increase in the CPI. B\&V found that between 
1992 and 2004, wastewater charges increased 47 percent, versus 31 percent for the CPI (All Urban).

If one assumes a constant rate of increase (linearity), increases for water and wastewater rates can be projected using three scenarios based on the average percentage increase for water and wastewater, the CPI - All Urban (AU) and the CPI - Water and Sewage Maintenance (WSU). The projections are reported in Table 10.

Table 10. Projected Increases in Rates and CPI

\begin{tabular}{|c|c|c|c|c|c|c|}
\hline & \multicolumn{3}{|c|}{ Water Rate Projections } & \multicolumn{3}{|c|}{ Wastewater Rate Projections } \\
\hline Year & $\begin{array}{c}\text { Water Rate } \\
\text { Increase } \\
(4.1 \%) \\
\text { (\$/kgal) }\end{array}$ & $\begin{array}{c}C P I(A U) \\
(2.3 \%) \\
(\$ / \mathrm{kgal})\end{array}$ & $\begin{array}{c}C P I \\
(\text { WSM }) \\
(3.7 \%) \\
(\$ / \text { kgal })\end{array}$ & $\begin{array}{c}\text { Wastewater } \\
\text { Rate } \\
\text { Increase } \\
(4.3 \%) \\
(\$ / \mathrm{kgal})\end{array}$ & $\begin{array}{c}C P I(A U) \\
(2.3 \%) \\
(\$ / k g a l)\end{array}$ & $\begin{array}{c}C P I \\
(\text { WSM }) \\
(3.7 \%) \\
(\$ / \mathrm{kgal})\end{array}$ \\
\hline 2004 & $\$ 2.13$ & & & $\$ 2.27$ & & \\
\hline 2005 & $\$ 2.22$ & 2.17 & 2.20 & $\$ 2.37$ & 2.32 & 2.36 \\
\hline 2010 & 2.74 & $\$ 2.44$ & 2.64 & 2.91 & 2.60 & 2.83 \\
\hline 2015 & 3.38 & 2.73 & 3.17 & 3.60 & 2.92 & 3.39 \\
\hline 2020 & 4.17 & 3.06 & 3.80 & 4.44 & 3.27 & 4.06 \\
\hline
\end{tabular}

Increases used: 4.3 percent for water, 4.1 percent for wastewater, 2.3 percent for the CPI (AU), and 3.7 percent for the CPI (WSM).

Source for All Urban CPI, http://www.eia.doe.gov/oiaf/aeo/excel/aeotab_19.xls; 2004 Water and Wastewater Rates (RFC 2004)

Water and wastewater rates may increase in a non-linear trend. The Annual Energy Outlook projects the CPI for All Urban to make energy-related predictions, Table 11.

Table 11. AEO Predictions for CPI (AU)

\begin{tabular}{|c|c|}
\hline Year & $\begin{array}{c}\text { AEO Predictions for } \boldsymbol{C P I} \\
(\boldsymbol{A U})(\mathbf{1 9 8 2 - 8 4}=\mathbf{1 . 0})\end{array}$ \\
\hline 2005 & 1.95 \\
\hline 2010 & 2.16 \\
\hline 2015 & 2.36 \\
\hline 2020 & 2.61 \\
\hline
\end{tabular}

\section{CONCLUSIONS}

The best data currently available for determining water and wastewater rates nationwide are contained in the RFC 2004 survey. Although coverage is greater in some regions than in others, the RFC data provide nationwide coverage in a format that enables calculation of marginal rates. 
The surveys that provide trend data indicate that, at least for the past decade or so, water and wastewater rates have increased significantly more than has the CPI. These increases mean that each 750-gallon unit saved has become increasingly valuable. If this trend continues, the savings realized by water conservation or efficiency programs will continue to increase.

\section{REFERENCES}

Black and Veatch. 2006 California Water Rate Survey. 2006. Black \& Veatch Enterprise Management Solutions: Los Angeles, CA.

Black and Veatch. California Wastewater Charge Survey. 2004. Black \& Veatch Corporation Enterprise Consulting: Irvine, CA.

Bureau of Labor Statistics. Consumer Price Index. US City Average, Water and Sewerage Maintenance, Base Period 1982-84 = 100, http://www.bls.gov/cpi/home.htm" \l "data, http://data.bls.gov/PDQ/outside.jsp? survey=cu

Department of Energy. December 2006 Annual Energy Outlook. http://www.eia.doe.gov/oiaf/aeo/excel/aeotab_19.xls

Fisher, D.C., and J.D. Lutz. Water and Waste Water Tariffs for New Residential Construction in California. 2006. Lawrence Berkeley National Laboratory: Berkeley, CA. Publication No. LBNL-60429, Draft Report.

National Association of Clean Water Agencies. 2005 Financial Survey: A National Survey of Municipal Wastewater Management Financing and Trends. 2005. National Association of Clean Water Agencies: Washington, D.C.

Raftelis/American Water Works Association. 2004 Water and Wastewater Survey. 2004. Raftelis Financial Corporation: Charlotte, NC, and American Water Works Association: Denver, CO. 